\title{
Proposed Model of Neutral Temperature Equation for Adaptive Thermal Comfort in Student Flats Units in the Tropics
}

\author{
Samsuddin ${ }^{1, *}$, Ramli Rahim², Baharuddin Hamzah', Rosady Mulyadi ${ }^{2}$ \\ ${ }^{1}$ Department of Architecture, Faculty of Engineering, Hasanuddin University, Indonesia \\ ${ }^{2}$ Laboratory of Building Science and Technology, Department of Architecture, Faculty of Engineering, Hasanuddin University, \\ Indonesia
}

Received December 31, 2020; Revised March 1, 2021; Accepted March 12, 2021

\section{Cite This Paper in the following Citation Styles}

(a): [1] Samsuddin, Ramli Rahim, Baharuddin Hamzah, Rosady Mulyadi, "Proposed Model of Neutral Temperature Equation for Adaptive Thermal Comfort in Student Flats Units in the Tropics, "Civil Engineering and Architecture, Vol. 9 , No. 2, pp. 477-492, 2021. DOI: 10.13189/cea.2021.090220.

(b): Samsuddin, Ramli Rahim, Baharuddin Hamzah, Rosady Mulyadi (2021). Proposed Model of Neutral Temperature Equation for Adaptive Thermal Comfort in Student Flats Units in the Tropics. Civil Engineering and Architecture, 9(2), 477-492. DOI: 10.13189/cea.2021.090220.

Copyright $\subseteq 2021$ by authors, all rights reserved. Authors agree that this article remains permanently open access under the terms of the Creative Commons Attribution License 4.0 International License

\begin{abstract}
Thermal comfort of residential rental flats is one of the problems from the ventilation aspect considering that the planning of flats is based on natural ventilation. This article is intended to formulate an alternative to the neutral temperature equation from the equation proposed by Humphrey, Auliciem, de Dear, Nicol, and Roaf with day and night measurement times. Measurements were carried out for three weeks in a student rental apartment building, Hasanuddin University Faculty of Engineering in Bontomarannu, Gowa Regency, which has 5 floors with 104 rooms. Measurements were made with 2,577 respondents during the day, and 2,043 at night. During the day, with an operating temperature between $29.2^{\circ} \mathrm{C}$ to $31.0^{\circ} \mathrm{C}$, the neutral temperature $(\mathrm{Tn})$ obtained from the PMV model is $27.6^{\circ} \mathrm{C}\left(\mathrm{T}_{\mathrm{o}}\right)$. This figure is lower than the actual choice of the TSV scale and the TCV scale, which were $30.3^{\circ} \mathrm{C}\left(\mathrm{T}_{\mathrm{o}}\right)$ and $29.7^{\circ} \mathrm{C}\left(\mathrm{T}_{\mathrm{o}}\right)$, respectively. At night, with an operating temperature between $27.7^{\circ} \mathrm{C}$ to $29.5^{\circ} \mathrm{C}$, the neutral temperature $\left(\mathrm{T}_{\mathrm{n}}\right)$ obtained from the PMV model is $26.2^{\circ} \mathrm{C}\left(\mathrm{T}_{\mathrm{o}}\right)$. Meanwhile, the neutral temperature obtained from the respondents' actual choices (TSV and TCV) were $28.8^{\circ} \mathrm{C}\left(\mathrm{T}_{\mathrm{o}}\right)$ and $28.2^{\circ} \mathrm{C}\left(\mathrm{T}_{\mathrm{o}}\right)$, respectively. The neutral temperature equations presented in the Humphrey, Auliciem, de Dear, Nicol, and Roaf equations show a lower thermal coefficient than the corrected thermal coefficient and the elaboration of the equations carried out in this study, both from daytime measurements and from night
\end{abstract}

measurements.

Keywords Neutral Temperature Equation, Thermal Comfort, Daytime, Nighttime

\section{Introduction}

Thermal comfort is defined as a "state of mind expressing satisfaction with the thermal environment" as described in ASHRAE [1]. Thermal comfort plays a very strategic role in building design, because most or about $80 \%$ of the time people's activities are done indoors [2]. From the aspect of energy use, Perez-Lombard stated that $70 \%$ of energy use in buildings is allocated for air conditioning and artificial lighting. Therefore, buildings need to be designed to respond to climatic conditions while maintaining the comfort of the occupants [3].

The level of productivity and physical endurance (health) of humans is in a certain zone, while outside this zone human productivity and physical endurance decrease. This zone is related to comfort, where according to reports from various studies it is different between groups of people who live in different climatic locations. The British have a comfort zone of $15^{\circ} \mathrm{C}$ to $20^{\circ} \mathrm{C}$ while the humans who live in the United States achieve comfort levels between $19.5^{\circ} \mathrm{C}$ and $26.7^{\circ} \mathrm{C}$, while those who live in the 
tropics achieve a comfortable level in the temperature. $23.4^{\circ} \mathrm{C}$ to $29.4^{\circ} \mathrm{C}$, all at humidity conditions between 30 to $70 \%$ [4].

Thermal comfort research in the tropics is important given that there is a significant increase in the mean annual temperature. Harimi [5] explained that when the climate data for the Kota Kinabalu area were analyzed, it was found that the trend of maximum outdoor temperature increase per decade was around $0.4^{\circ} \mathrm{C}$ with an average outdoor temperature increase of $0.3^{\circ} \mathrm{C}$. The maximum outdoor temperature appears to be increasing faster than the average value.

Human thermal comfort sensation depends partly on his activity and clothing and partly on four environmental variables: air temperature, average emission temperature, air velocity, and humidity. Fanger [6] introduces a comfort equation forming all the combinations of the six factors mentioned above that will provide thermal comfort to humans. The convenience equation does not include time of day as a variable, but assumes that the comfort criterion is constant throughout the day. Fanger [7] in the study of thermal comfort conditions during simulated normal working days at the office and found no significant difference in the preferred ambient temperature during the 'morning and evening hours. Likewise with research conducted in 1974 by Fanger [8] who carried out investigations into thermal comfort in the morning (09.00-12.00) and in the evening (19.00-22.00) which did not found significant differences in the preferred ambient temperature at these two times.

Various studies on thermal comfort in the tropics have been carried out, including in Indonesia [9,10], Malaysia [11], and Singapore [12]. Most of the thermal comfort studies in the tropics are carried out with a heat balance model using the Predicted Mean Vote (PMV). In 1970 Fanger developed the PMV model which was later adopted by ASHRAE as the ASHRAE 55 standard [13]. The PMV model is calculated using six variables, namely air temperature, relative humidity, mean radian temperature (MRT), air velocity, clothing index, and the metabolic rate of the respondent's activity. A number of studies of thermal comfort in the tropics mentioned above found the neutral temperature predicted by PMV to be significantly lower than that of the respondents using the respondent's choice of thermal sensation (TSV). Several studies conducted by Hamzah $[10,14]$ found that the students' neutral temperature was at $23.0^{\circ} \mathrm{C}$ (PMV) and $29.0^{\circ} \mathrm{C}$ (TSV). Karyono also found this difference in numbers [15] which revealed that the ISO-7730 and ASHRAE 55-56 standards were about $1-3^{\circ} \mathrm{C}$ lower than the comfortable temperature required by respondents in tropical regions such as Indonesia. Such conditions will have implications for wasteful energy use and complaints of discomfort due to low room temperature.

The general condition of rental apartment units built in Indonesia, including Makassar City, is a residential building that is mostly subsidized or assisted with technical requirements that direct the use of a building ventilation system with natural ventilation [16]. With thermal conditions tinged with temperatures varying from $28^{\circ} \mathrm{C}$ in the morning to $33^{\circ} \mathrm{C}$ in the afternoon [14]. This temperature range is outside the comfort zone by Indonesian local standards [17] and ASHRAE standards [1]. However, a number of studies of thermal comfort in Makassar City found that despite the hot temperature, more than $80 \%$ of respondents chose a "comfortable" area and more than $80 \%$ of students received a "hot" thermal environment. Adaptation activities that are usually carried out by respondents in order to adjust their thermal comfort needs with the temperature conditions in the room, including the use of fans, changes in activities, clothes, opening and closing windows, changing fans and so on. Roaf et al. [18] suggested that there are three categories of thermal comfort adaptation activities, namely physiological, behavioral, and psychological. Of the three adaptation activities, behavioral adaptation is the most common way for people to adjust their thermal comfort.

Another thermal comfort concept is the adaptive thermal comfort model developed by Humphrey [19] based on thermal comfort data collected from 1935 to 1975. This concept is specially formulated to predict thermal comfort in naturally ventilated buildings located in tropical areas with hot thermal environments. The concept is put forward in the form of linear regression between neutral temperature ( $\mathrm{Tn})$ and average outside temperature (Tout) as follows:

$$
\mathrm{T}_{n}=11,9+0,534 \mathrm{~T}_{\text {out }}
$$

The equation is then revised to improve the accuracy of the equation as follows [20]:

$$
\mathrm{T}_{n}=13,2+0,534 \mathrm{~T}_{\text {out }}
$$

This equation was further refined in 1988 by formulating the following equation [20]:

$$
\mathrm{T}_{n}=13.5+0.546 \mathrm{~T}_{\text {out }}
$$

Auliciems [21] develop a neutral temperature formula by stating the following equation:

$$
\mathrm{T}_{n}=9.22+0.48 \mathrm{Ta}+0.14 \mathrm{~T}_{\text {out }}
$$

Auliciems dan de Dear [22] propose another equation with the following formula:

$$
\mathrm{T}_{n}=17.6+0.31 \mathrm{~T}_{\text {out }}
$$

Nicol dan Roaf [23] suggests a different equation by proposing the following formula:

$$
\mathrm{T}_{n}=17+0.38 \mathrm{~T}_{\text {out }}
$$

A number of equations mentioned above are based on research on thermal comfort conducted in Indonesia [14], showing a neutral temperature below the neutral temperature figure based on actual measurements with the TSV model, both for general building functions, and for residential buildings with effective day and night activities. Therefore, this study aims to analyze the neutral 
temperature equation above based on tropical climatic conditions characterized by relatively high temperature and humidity.

\section{Research Method}

Measurements were made in student apartment units which are five-story buildings. Measurements were carried out every day in twelve rooms spread over five floors simultaneously. This is intended to obtain thermal conditions which represent the general thermal conditions of buildings. The downside of this measurement is that it doesn't specifically differentiate between thermal conditions on different floors.

The proposed neutral temperature equation is obtained by changing the existing equation constants according to the actual value of the internal temperature measurement results against the thermal conditions at the research location, both during the day and at night.

\subsection{Data Collection}

The data used as the object of study consists of four data components including: outdoor temperature data for the period 2014-2019, outdoor temperature data for the period of October 2020, objective data measurement results, and subjective data measurement results.

\subsubsection{Outdoor Temperature Data for the Period 2014-2019}

Data on temperature and relative humidity for outdoor space on a 6-year scale for the period 2014-2019 obtained from the weather monitoring tool Vaisala Type WXT520 which is equipped with data loggers Type CR800 series 2 which automatically stores data for a 24 hour period, RTU (Remote Terminal Unit), which is part of the AWS (Automatic Weather Stations) device on the campus data station of the Faculty of Engineering, Unhas Gowa.

\subsubsection{Outdoor Temperature Data for the Period of October 2020}

Temperature and relative humidity data for the out space for the period of October 2020 were obtained from the Vaisala Type WXT520 weather monitor. This data is obtained from the same instrument to measure 6-year scale data for the 2014-2019 period.

\subsubsection{Objective Data Measurement Results}

The results of objective data measurements are carried out to collect thermal environmental conditions and clothing data of respondents. The main instrument used in this study was the Thermal Comfort Multi Logger (LSI TC) from LSI-Lastem, Italy. LSI TC consists of three sensors that collect and record in one data logger. Tiga sensor termasuk psikometrik portabel probe (BSU102), which is used to record temperature and humidity relative humidity data. The second sensor is a Globe
Thermometric Probe (BST131) which is used to record the temperature of the globe. The third sensor is a wet-bulb temperature probe (BSU121) for recording the wet-bulb temperature. Apart from LSI TC, another instrument used is Hobo Loggers which records measurements of the thermal environment in space. This tool was developed and manufactured by Onset in the United States. Two types of loggers Hobo are used in this study, namely the standard Hobo which records air temperature and relative humidity, and the Hobo logger with an external sensor that records air velocity in the room. This instrument (LSI TC), 2 hobo loggers with external sensors, and 3 standard hobo units are spread out in 6 rooms simultaneously on the same floor level with a continuous data recording period of 24 hours with the number of days that have been arranged. The sensor is installed at a height of approximately 1 meter above the floor level [12]. Respondent clothing data is an integral part of the questionnaire.

\subsubsection{Subjective Data Measurement}

Subjective measurements were carried out to record respondents' responses using a questionnaire instrument developed and modified based on the questionnaire used by Wong and Khoo [12]. The questionnaire used contains seven questions. Four questions are related to the thermal aspect, namely thermal sensation, thermal comfort, thermal preference and acceptance, the fifth and sixth questions concern air velocity, and the seventh question concerns indoor humidity. Questions about TSV cover the seven ASHRAE scales consisting of cold (-3), cool (-2), slightly cool (-1), neutral (0), slightly warm $(+1)$, warm $(+2)$, and hot (+3). Questions about the TCV covering the seven Bedford scale consist of: much too cool $(-3)$, too cool (-2), comfortable cool (-1), comfortable (0), comfortable warm $(+1)$, too warm $(+2)$, and much too warm $(+3)$. This subjective measurement was carried out by taking two times scales, namely during the day between 10:00-15:40 and evening between 18:00-21:40 hours. This is done considering the function of the building as a function of housing.

Annual temperature conditions for the period 2014-2019 show the temperature conditions measured by day and night where there is a significant difference between the average daytime and night temperatures of $2.0^{\circ} \mathrm{C}$. The maximum daytime temperature was recorded at $29.5^{\circ} \mathrm{C}$ in 2016 and the minimum temperature was $28.8^{\circ} \mathrm{C}$ in 2019 . The maximum nighttime temperature was recorded at $30.5^{\circ} \mathrm{C}$ in 2017 and the minimum temperature was $24.9^{\circ} \mathrm{C}$ in 2015 . Average air temperature during the day recorded in the 2014-2019 measurement period it was higher than the average air temperature measured in the 1968-2003 period [5].

\subsection{Data Processing and Analysis}

Data processing and analysis were carried out using 
spreadsheet software and statistical packages which were used to calculate the maximum value, minimum value, and average value as the basis for describing the PMV, TSV, and TCV charts. The PMV of each respondent was calculated using data from four environmental variables and two personal variables. Four environmental variables include air temperature, average radiant temperature, relative air velocity, and relative humidity. Two personal variables include data on clothing and metabolic rate. The PMV value of respondents was determined using the PMV calculator developed by Farina [24] based on ASHRAE standard 55 [1]. Linear regression of PMV, TSV, and TCV was performed using SPSS statistical analysis (statistical package for social science) to show the distribution of respondents' actual voices to operating temperature (To). Data validity and reliability tests are carried out prior to data processing in order to ensure data normality.

\subsection{Research Samples}

The survey and objective data measurement were carried out for three weeks (21 days) in the Rusunawa building, Bontomarannu Engineering Faculty, Gowa Regency. This building is a 5-storey building with 104 rooms divided into 16 rooms on the ground floor and 22 rooms on the 2,3,4, and 5 floors. Measurements are carried out 24 hours a day to obtain temperature data that represents daytime and night considering the function of the building as a residential unit. The characteristics of the day and night measurement samples are described in Table 1 and Table 2 below.

Table 1. Characteristics of Sample Based on Survey During the Daytime

\begin{tabular}{|c|c|c|c|c|}
\hline No. & Date of Survey & Floor Level & Number of Rooms & Number of Respondents \\
\hline 1 & 1 October 2020 & 1 & 9 & 108 \\
\hline 2 & 2 October 2020 & 1 & 9 & 128 \\
\hline 3 & 3 October 2020 & 1 & 12 & 133 \\
\hline 4 & 4 October 2020 & 1 & 12 & 128 \\
\hline 5 & 5 October 2020 & 2 & 12 & 88 \\
\hline 6 & 6 October 2020 & 2 & 12 & 127 \\
\hline 7 & 7 October 2020 & 2 & 12 & 134 \\
\hline 8 & 8 October 2020 & 2 & 12 & 97 \\
\hline 9 & 9 October 2020 & 2 & 12 & 133 \\
\hline 10 & 10 October 2020 & 3 & 12 & 126 \\
\hline 11 & 11 October 2020 & 3 & 12 & 134 \\
\hline 12 & 12 October 2020 & 3 & 12 & 134 \\
\hline 13 & 13 October 2020 & 3 & 12 & 134 \\
\hline 14 & 14 October 2020 & 4 & 12 & 134 \\
\hline 15 & 15 October 2020 & 4 & 12 & 127 \\
\hline 16 & 16 October 2020 & 4 & 12 & 127 \\
\hline 17 & 17 October 2020 & 4 & 12 & 107 \\
\hline 18 & 18 October 2020 & 5 & 12 & 133 \\
\hline 19 & 19 October 2020 & 5 & 12 & 100 \\
\hline 20 & 20 October 2020 & 5 & 12 & 124 \\
\hline 21 & 21 October 2020 & 5 & 12 & 121 \\
\hline Total & & & 246 & 2,577 \\
\hline
\end{tabular}


Table 2. Sample Characteristics Based on Survey at Nighttime

\begin{tabular}{|c|c|c|c|c|}
\hline No. & Date of Survey & Floor Level & Number of Rooms & Number of Respondents \\
\hline 1 & 1 October 2020 & 1 & 9 & 84 \\
\hline 2 & 2 October 2020 & 1 & 9 & 101 \\
\hline 3 & 3 October 2020 & 1 & 12 & 106 \\
\hline 4 & 4 October 2020 & 1 & 12 & 85 \\
\hline 5 & 5 October 2020 & 2 & 12 & 71 \\
\hline 6 & 6 October 2020 & 2 & 12 & 106 \\
\hline 7 & 7 October 2020 & 2 & 12 & 107 \\
\hline 8 & 8 October 2020 & 2 & 12 & 102 \\
\hline 9 & 9 October 2020 & 2 & 12 & 101 \\
\hline 10 & 10 October 2020 & 3 & 12 & 74 \\
\hline 11 & 11 October 2020 & 3 & 12 & 100 \\
\hline 12 & 12 October 2020 & 3 & 12 & 107 \\
\hline 13 & 13 October 2020 & 3 & 12 & 106 \\
\hline 14 & 14 October 2020 & 4 & 12 & 107 \\
\hline 15 & 15 October 2020 & 4 & 12 & 106 \\
\hline 16 & 16 October 2020 & 4 & 12 & 100 \\
\hline 17 & 17 October 2020 & 4 & 12 & 101 \\
\hline 18 & 18 October 2020 & 5 & 12 & 98 \\
\hline 19 & 19 October 2020 & 5 & 12 & 106 \\
\hline 20 & 20 October 2020 & 5 & 12 & 80 \\
\hline 21 & 21 October 2020 & 5 & 12 & 95 \\
\hline Total & & & 246 & 2,043 \\
\hline
\end{tabular}

\section{Result and Discussion}

\subsection{Outdoor and Indoor Microclimate Conditions}

Outdoor microclimate condition data is data obtained from the weather monitoring tool Vaisala which is located at the top of the campus building of the Bontomarannu Faculty of Engineering, Gowa Regency. Average outdoor temperature the room recorded in October during the day is $29.6^{\circ} \mathrm{C}$ with a maximum temperature of $30.9^{\circ} \mathrm{C}$ and a minimum temperature of $27.3^{\circ} \mathrm{C}$. While the average temperature at night is $26.4^{\circ} \mathrm{C}$, the maximum temperature is $28.0^{\circ} \mathrm{C}$ and the minimum temperature is $22.7^{\circ} \mathrm{C}$.
Data on indoor microclimate conditions from day and night measurements that are recorded during the measurement can be seen in Table 3. This table shows that the average indoor air temperature during the day is $31.6^{\circ} \mathrm{C}$ with the maximum and minimum temperatures respectively $32.3^{\circ} \mathrm{C}$ and $30.6^{\circ} \mathrm{C}$. Air temperature conditions indicate relatively high temperature conditions in the room. The average temperature recorded during the day and night is higher than the local Indonesian thermal comfort standards [17] and ASHRAE international standards [1]. The average relative humidity during the day and night was $71.78 \%$ and $74.05 \%$, respectively. As with temperature, the relative humidity conditions are well above Indonesia's thermal comfort standards [17]. 
Table 3. The Average Indoor Thermal Environment

\begin{tabular}{|c|c|c|c|c|c|c|c|c|c|c|c|c|c|c|c|c|}
\hline \multirow{3}{*}{ Date of survey } & \multirow{2}{*}{$\begin{array}{c}\text { Afternoon } \\
\text { Operational } \\
\text { Temperature }\end{array}$} & \multirow{2}{*}{$\begin{array}{l}\text { Afternoon } \\
\text { MRT }\end{array}$} & \multicolumn{3}{|c|}{$\begin{array}{c}\text { Afternoon Indoor } \\
\text { Temperature }\end{array}$} & \multirow{2}{*}{$\begin{array}{c}\text { Night } \\
\text { Operational } \\
\text { Temperature }\end{array}$} & \multirow{2}{*}{$\begin{array}{l}\text { Night } \\
\text { MRT }\end{array}$} & \multicolumn{3}{|c|}{ Night Indoor Temperature } & \multicolumn{3}{|c|}{$\begin{array}{c}\text { Relative Humidity } \\
\text { (Afternoon) }\end{array}$} & \multicolumn{3}{|c|}{ Relative Humidity (Night)) } \\
\hline & & & Average & Max & Min & & & Average & Max & Min & Average & Max & Min & Average & Max & Min \\
\hline & $\left({ }^{\circ} \mathrm{C}\right)$ & $\left({ }^{\circ} \mathrm{C}\right)$ & $\left({ }^{\circ} \mathrm{C}\right)$ & $\left({ }^{\circ} \mathrm{C}\right)$ & $\left({ }^{\circ} \mathrm{C}\right)$ & $\left({ }^{\circ} \mathrm{C}\right)$ & $\left({ }^{\circ} \mathrm{C}\right)$ & $\left({ }^{\circ} \mathrm{C}\right)$ & $\left({ }^{\circ} \mathrm{C}\right)$ & $\left({ }^{\circ} \mathrm{C}\right)$ & $\%$ & $\%$ & $\%$ & $\%$ & $\%$ & $\%$ \\
\hline 1 October 2020 & 30.8 & 29.6 & 32.0 & 33.3 & 28.7 & 29.3 & 29.0 & 29.6 & 30.9 & 26.5 & 79.66 & 85.13 & 69.10 & 81.32 & 89.55 & 70.53 \\
\hline 2 October 2020 & 30.8 & 29.5 & 32.1 & 33.4 & 28.8 & 29.3 & 28.9 & 29.7 & 31.0 & 26.6 & 75.58 & 84.11 & 68.59 & 77.02 & 84.80 & 67.12 \\
\hline 3 October 2020 & 30.2 & 28.7 & 31.7 & 33.0 & 28.4 & 28.7 & 28.4 & 29.0 & 30.1 & 25.8 & 70.99 & 78.22 & 61.97 & 73.41 & 80.78 & 62.94 \\
\hline 4 October 2020 & 30.0 & 28.7 & 31.3 & 32.8 & 28.2 & 28.6 & 28.2 & 28.9 & 30.2 & 25.9 & 70.73 & 77.76 & 61.95 & 72.57 & 80.12 & 62.78 \\
\hline 5 October 2020 & 31.0 & 29.7 & 32.3 & 33.7 & 29.0 & 29.5 & 29.0 & 29.9 & 31.3 & 26.9 & 80.36 & 85.50 & 75.02 & 81.78 & 90.45 & 70.89 \\
\hline 6 October 2020 & 30.3 & 28.8 & 31.8 & 33.1 & 28.5 & 28.8 & 28.4 & 29.2 & 30.4 & 26.2 & 71.26 & 79.29 & 62.37 & 73.57 & 81.16 & 63.78 \\
\hline 7 October 2020 & 30.4 & 29.0 & 31.8 & 33.2 & 28.6 & 29.0 & 28.4 & 29.5 & 30.7 & 26.4 & 71.54 & 79.45 & 62.99 & 74.14 & 81.76 & 64.23 \\
\hline 8 October 2020 & 29.4 & 28.0 & 30.8 & 32.1 & 27.7 & 28.0 & 27.2 & 28.7 & 30.1 & 25.8 & 68.24 & 74.11 & 58.24 & 70.59 & 76.89 & 61.22 \\
\hline 9 October 2020 & 30.7 & 29.3 & 32.1 & 33.5 & 28.8 & 29.2 & 28.5 & 29.9 & 31.3 & 26.7 & 74.34 & 82.82 & 65.31 & 76.28 & 83.23 & 66.78 \\
\hline 10 October 2020 & 30.5 & 29.1 & 31.9 & 33.2 & 28.6 & 29.0 & 28.5 & 29.5 & 30.8 & 26.5 & 72.03 & 82.78 & 64.97 & 75.17 & 82.54 & 65.21 \\
\hline 11 October 2020 & 29.9 & 28.5 & 31.3 & 32.7 & 28.2 & 28.4 & 27.9 & 29.0 & 30.1 & 25.8 & 70.22 & 77.07 & 61.90 & 72.28 & 79.69 & 62.68 \\
\hline 12 October 2020 & 30.7 & 29.5 & 31.9 & 33.4 & 28.7 & 29.2 & 28.7 & 29.8 & 31.2 & 26.7 & 75.25 & 83.14 & 67.52 & 76.93 & 83.90 & 66.80 \\
\hline 13 October 2020 & 30.5 & 29.0 & 32.0 & 33.3 & 28.7 & 29.0 & 28.5 & 29.5 & 30.8 & 26.5 & 71.98 & 82.08 & 63.93 & 74.36 & 81.99 & 64.45 \\
\hline 14 October 2020 & 29.5 & 28.0 & 31.0 & 32.3 & 27.9 & 28.1 & 27.4 & 28.7 & 30.1 & 25.8 & 68.51 & 74.36 & 58.34 & 70.94 & 78.32 & 61.53 \\
\hline 15 October 2020 & 29.9 & 28.3 & 31.5 & 32.9 & 28.3 & 28.4 & 27.9 & 29.0 & 30.1 & 25.9 & 69.71 & 75.57 & 61.76 & 72.21 & 79.53 & 62.66 \\
\hline 16 October 2020 & 30.5 & 29.1 & 31.9 & 33.3 & 28.6 & 29.0 & 28.5 & 29.5 & 30.8 & 26.5 & 71.99 & 82.55 & 64.72 & 74.65 & 82.12 & 64.57 \\
\hline 17 October 2020 & 30.5 & 29.1 & 31.9 & 33.3 & 28.7 & 29.0 & 28.5 & 29.6 & 30.9 & 26.4 & 73.71 & 82.80 & 65.00 & 75.70 & 82.64 & 65.58 \\
\hline 18 October 2020 & 29.4 & 27.9 & 30.9 & 32.2 & 27.7 & 27.9 & 27.2 & 28.6 & 30.0 & 25.6 & 67.30 & 73.97 & 54.04 & 69.67 & 76.89 & 60.54 \\
\hline 19 October 2020 & 29.8 & 28.1 & 31.5 & 32.8 & 28.2 & 28.3 & 27.7 & 28.9 & 30.2 & 25.9 & 69.39 & 75.47 & 58.75 & 71.59 & 78.98 & 62.00 \\
\hline 20 October 2020 & 29.2 & 27.8 & 30.6 & 32.0 & 27.6 & 27.7 & 27.1 & 28.3 & 29.6 & 25.4 & 65.98 & 73.10 & 42.62 & 69.50 & 76.65 & 60.29 \\
\hline 21 October 2020 & 29.7 & 28.1 & 31.3 & 32.6 & 28.1 & 28.2 & 27.4 & 29.0 & 30.2 & 26.0 & 68.51 & 75.27 & 58.39 & 71.46 & 78.78 & 61.88 \\
\hline Average & 30.2 & 28.8 & 31.6 & 33.0 & 28.4 & 28.7 & 28.2 & 29.2 & 30.5 & 26.2 & 71.78 & 79.26 & 62.26 & 74.05 & 81.47 & 64.21 \\
\hline Max & 31.0 & 29.7 & 32.3 & 33.7 & 29.0 & 29.5 & 29.0 & 29.9 & 31.3 & 26.9 & 80.36 & 85.50 & 75.02 & 81.78 & 90.45 & 70.89 \\
\hline Min & 29.2 & 27.8 & 30.6 & 32.0 & 27.6 & 27.7 & 27.1 & 28.3 & 29.6 & 25.4 & 65.98 & 73.10 & 42.62 & 69.50 & 76.65 & 60.29 \\
\hline
\end{tabular}




\subsection{Respondents' Responses to the Thermal Environment based on Thermal Balance}

Respondents' responses to the thermal environment inside the building during the day and night can be seen in table 4. During the day on the TSV scale, $31.04 \%$ chose a neutral area $(0), 27.01 \%$ chose a slightly cool $(-1), 10.36 \%$ chose cool (-2), $1.59 \%$ chose cold $(-3), 19.17 \%$ chose slightly warm $(+1), 7.53 \%$ chose warm $(+2)$, and $3.30 \%$ chose hot $(+3)$. On the TCV scale, $40.55 \%$ chose comfortable (0), $12.03 \%$ chose comfortable cool (-1), $5.28 \%$ chose too cool $(-2), 0.31 \%$ chose much too cool $(-3)$, $24.13 \%$ chose comfortable warm $(+1), 6.69 \%$ chose too warm (+2), and $1.49 \%$ chose much too warm $(+3)$. Table 5 provides an overview of the respondents' responses to the thermal environment inside the building at night. On the TSV scale, $30.79 \%$ chose a neutral area (0), $26.97 \%$ chose slightly cool (-1), $10.38 \%$ chose cool $(-2), 1.52 \%$ chose cold $(-3), 19.24 \%$ preferred slightly warm $(+1), 7.54 \%$ chose warm $(+2)$, and $3.57 \%$ chose hot $(+3)$. On the TCV scale, $40.63 \%$ chose comfortable $(0), 11.89 \%$ chose comfortable cool (-1), 5.34\% chose too cool (-2), $0.29 \%$ chose much too cool (-3), 32.35\% chose comfortable warm $(+1), 6.85 \%$ chose too warm $(+2)$, and $2.68 \%$ much too warm $(+3)$.

The data presented in Figure 1 contain the percentage of respondents 'choice of thermal sensation, thermal comfort and prediction of the average choice of respondents during the day, which can be explained that the average prediction of respondents' choices is relatively different from the TSV scale and the TCV scale. In the prediction model (PMV), there are $75.28 \%$ of respondents predicted to choose hot areas $(+2$ and +3$), 24.72 \%$ of respondents predicted to choose the middle area $(-1,0$, and +1$)$. If you compare the predictions of respondents who choose in the middle area $(-1,0$, and +1$)$ with the respondents' choices on the TSV and TCV scales figures $77.22 \%$ and $85.06 \%$, It can be explained that the predicted figures in the PMV model against the options in the middle region $(-1,0$, and +1$)$ are much lower than on the TSV and TCV scales. Likewise, the predictions of respondents who chose a slightly cool area (-1) on the TSV scale were $27.01 \%$ and a comfortable cool area (-1) on the TCV scale was $12.03 \%$ compared to $0 \%$ in the PMV model, and respondents who chose a slightly warm area $(+1)$ on the TSV scale as much as $19.17 \%$ and $32.48 \%$ of respondents chose a warm comfortable area $(+1)$ on the TCV scale which is also compared to $24.72 \%$ in the PMV model.

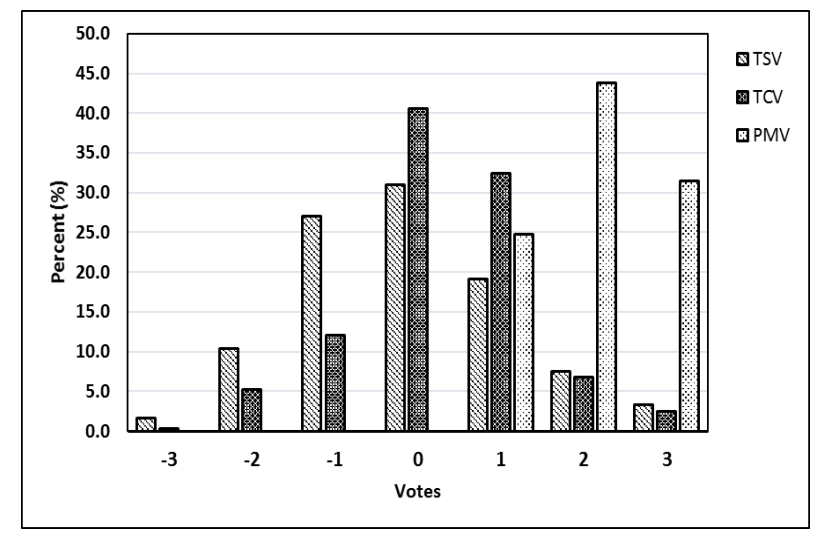

Figure 1. The Percentage of Thermal Sensation Votes, Thermal Comfort Vote, and the Predicted Mean Vote During the Day 
Table 4. Distribution of Respondents' Choice of TSV and TCV During the Day

\begin{tabular}{|c|c|c|c|c|c|c|c|c|c|c|c|c|c|c|}
\hline \multirow{3}{*}{ Date of survey } & \multicolumn{7}{|c|}{ TSV (Thermal Sensation Vote) } & \multicolumn{7}{|c|}{ TCV (Thermal Comfort Vote) } \\
\hline & cold & cool & $\begin{array}{c}\text { slightly } \\
\text { cool }\end{array}$ & neutral & $\begin{array}{l}\text { slightly } \\
\text { warm }\end{array}$ & warm & hot & $\begin{array}{c}\text { much too } \\
\text { cool }\end{array}$ & $\begin{array}{l}\text { too } \\
\text { cool }\end{array}$ & $\begin{array}{c}\text { comfortable } \\
\text { cool }\end{array}$ & comfortable & $\begin{array}{c}\text { comfortable } \\
\text { warm }\end{array}$ & too warm & $\begin{array}{c}\text { much too } \\
\text { warm }\end{array}$ \\
\hline & -3 & -2 & -1 & 0 & 1 & 2 & 3 & -3 & -2 & -1 & 0 & 1 & 2 & 3 \\
\hline 1 October 2020 & 0 & 6 & 23 & 37 & 27 & 11 & 4 & 0 & 2 & 6 & 46 & 45 & 8 & 1 \\
\hline 2 October 2020 & 0 & 8 & 31 & 45 & 32 & 8 & 4 & 0 & 5 & 23 & 49 & 37 & 8 & 6 \\
\hline 3 October 2020 & 0 & 6 & 29 & 46 & 33 & 13 & 6 & 0 & 9 & 6 & 58 & 51 & 8 & 1 \\
\hline 4 October 2020 & 0 & 16 & 44 & 42 & 18 & 8 & 0 & 0 & 10 & 6 & 67 & 39 & 6 & 0 \\
\hline 5 October 2020 & 0 & 3 & 16 & 25 & 23 & 12 & 9 & 0 & 0 & 0 & 0 & 26 & 28 & 29 \\
\hline 6 October 2020 & 0 & 6 & 28 & 38 & 31 & 18 & 6 & 0 & 5 & 4 & 55 & 55 & 6 & 2 \\
\hline 7 October 2020 & 0 & 4 & 21 & 43 & 40 & 19 & 7 & 0 & 5 & 3 & 57 & 54 & 12 & 2 \\
\hline 8 October 2020 & 0 & 7 & 36 & 30 & 15 & 3 & 6 & 0 & 6 & 6 & 34 & 40 & 8 & 3 \\
\hline 9 October 2020 & 7 & 28 & 43 & 33 & 16 & 3 & 3 & 0 & 3 & 23 & 62 & 33 & 11 & 2 \\
\hline 10 October 2020 & 6 & 25 & 42 & 33 & 15 & 4 & 1 & 0 & 2 & 26 & 63 & 26 & 11 & 0 \\
\hline 11 October 2020 & 0 & 17 & 46 & 42 & 18 & 8 & 3 & 0 & 3 & 31 & 56 & 34 & 8 & 2 \\
\hline 12 October 2020 & 0 & 14 & 37 & 42 & 31 & 8 & 2 & 0 & 7 & 26 & 54 & 38 & 6 & 2 \\
\hline 13 October 2020 & 0 & 6 & 28 & 45 & 34 & 13 & 8 & 0 & 7 & 5 & 58 & 52 & 7 & 4 \\
\hline 14 October 2020 & 0 & 7 & 29 & 43 & 32 & 17 & 6 & 0 & 8 & 5 & 60 & 52 & 7 & 2 \\
\hline 15 October 2020 & 0 & 9 & 41 & 45 & 20 & 8 & 4 & 0 & 7 & 5 & 55 & 50 & 8 & 3 \\
\hline 16 October 2020 & 0 & 8 & 35 & 50 & 23 & 8 & 3 & 0 & 2 & 5 & 50 & 57 & 9 & 3 \\
\hline 17 October 2020 & 0 & 12 & 32 & 37 & 18 & 6 & 2 & 0 & 10 & 22 & 41 & 25 & 7 & 2 \\
\hline 18 October 2020 & 0 & 8 & 27 & 40 & 32 & 18 & 8 & 0 & 7 & 5 & 53 & 60 & 9 & 1 \\
\hline 19 October 2020 & 5 & 22 & 33 & 25 & 12 & 3 & 0 & 8 & 22 & 42 & 22 & 6 & 0 & 0 \\
\hline 20 October 2020 & 17 & 35 & 37 & 23 & 8 & 2 & 2 & 0 & 9 & 36 & 56 & 26 & 0 & 0 \\
\hline 21 October 2020 & 6 & 20 & 38 & 36 & 16 & 4 & 1 & 0 & 7 & 25 & 49 & 31 & 9 & 0 \\
\hline Number of choices & 41 & 267 & 696 & 800 & 494 & 194 & 85 & 8 & 136 & 310 & 1045 & 837 & 176 & 65 \\
\hline Percentage of choices & 1.59 & 10.36 & 27.01 & 31.04 & 19.17 & 7.53 & 3.30 & 0.31 & 5.28 & 12.03 & 40.55 & 32.48 & 6.83 & 2.52 \\
\hline Amount of data & & & & & & & 2577 & & & & & & & 2577 \\
\hline Percentage of total & & & & & & & 100 & & & & & & & 100 \\
\hline
\end{tabular}


Figure 2 contains data on the percentage of respondents' choice of thermal sensation, thermal comfort and the predicted average choice of respondents at night. This data shows that in the PMV model, there are $75.38 \%$ of respondents predicted to choose hot areas $(+2$ and +3$)$, $24.62 \%$ of respondents predicted to choose the middle area $(-1,0$, and +1$)$. When comparing the predictions of respondents who chose in the middle area $(-1,0$, and +1$)$ with the choice of respondents on the TSV and TCV scales at $77.00 \%$ and $84.87 \%$, it can be explained that the numbers predicted in the PMV model to the choices in the middle area $(-1,0$, and +1$)$ are much lower than the TSV and TCV scales. Likewise, the predictions of respondents who chose a slightly cool area (-1) on the TSV scale were $26.97 \%$ and a comfortable cool area (-1) on the TCV scale was $11.89 \%$ versus $0 \%$ on the PMV model, and respondents who chose a slightly warm area $(+1)$ on the TSV scale were $19.24 \%$ and $32.35 \%$ of respondents chose a warm comfortable area $(+1)$ on the TCV scale which was also compared to $24.62 \%$ in the PMV model. Based on the data elaborated in Figure 2 and Figure 3, it can then be explained that the results of research on thermal comfort were carried out in several regions such as Indonesia [9,10], Malaysia [11], and Singapore [12] find relatively the same phenomenon. Therefore, the PMV model can be said to be an irrelevant model to be applied in thermal comfort research, especially in naturally ventilated buildings in tropical areas such as Indonesia.

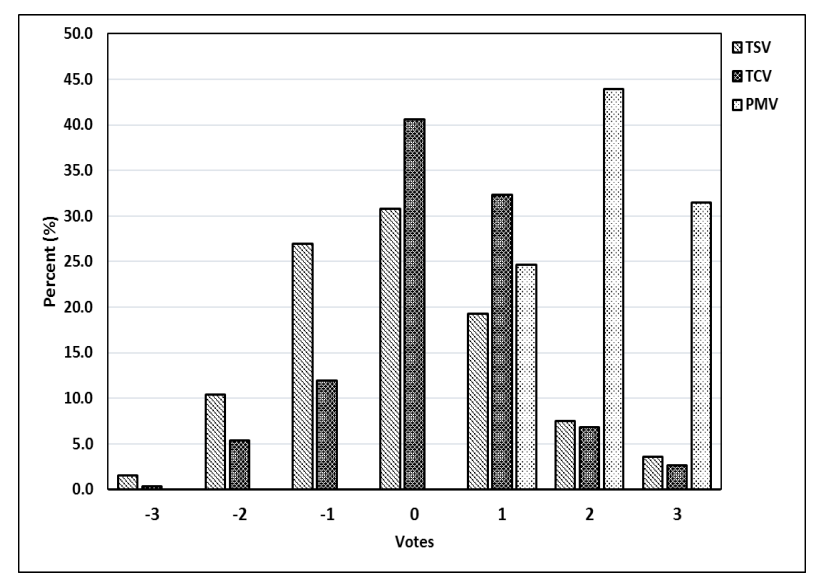

Figure 2. The Percentage of Thermal Sensation Votes, Thermal Comfort Vote, and the Predicted Mean Vote During the Evening 
Table 5. Distribution of Nightly Respondents' Choice of TSV and TCV

\begin{tabular}{|c|c|c|c|c|c|c|c|c|c|c|c|c|c|c|}
\hline \multirow{3}{*}{ Date of survey } & \multicolumn{7}{|c|}{ TSV (Thermal Sensation Vote) } & \multicolumn{7}{|c|}{ TCV (Thermal Comfort Vote) } \\
\hline & cold & cool & $\begin{array}{c}\text { slightly } \\
\text { cool }\end{array}$ & neutral & $\begin{array}{c}\text { slightly } \\
\text { warm }\end{array}$ & warm & hot & $\begin{array}{c}\text { much too } \\
\text { cool }\end{array}$ & $\begin{array}{l}\text { too } \\
\text { cool }\end{array}$ & $\begin{array}{c}\text { comfortable } \\
\text { cool }\end{array}$ & comfortable & $\begin{array}{c}\text { comfortable } \\
\text { warm }\end{array}$ & $\begin{array}{c}\text { too } \\
\text { warm }\end{array}$ & $\begin{array}{c}\text { much too } \\
\text { warm }\end{array}$ \\
\hline & -3 & -2 & -1 & 0 & 1 & 2 & 3 & -3 & -2 & -1 & 0 & 1 & 2 & 3 \\
\hline 1 October 2020 & 0 & 4 & 18 & 29 & 21 & 8 & 4 & 0 & 1 & 4 & 37 & 35 & 6 & 1 \\
\hline 2 October 2020 & 0 & 5 & 22 & 30 & 25 & 14 & 5 & 0 & 4 & 4 & 44 & 43 & 5 & 1 \\
\hline 3 October 2020 & 0 & 4 & 22 & 35 & 27 & 11 & 7 & 0 & 6 & 4 & 46 & 42 & 5 & 4 \\
\hline 4 October 2020 & 0 & 9 & 25 & 29 & 15 & 5 & 2 & 0 & 8 & 17 & 33 & 19 & 6 & 2 \\
\hline 5 October 2020 & 0 & 2 & 12 & 20 & 19 & 10 & 8 & 0 & 0 & 0 & 0 & 21 & 23 & 26 \\
\hline 6 October 2020 & 0 & 3 & 16 & 34 & 32 & 15 & 6 & 0 & 4 & 3 & 46 & 42 & 10 & 2 \\
\hline 7 October 2020 & 0 & 7 & 22 & 31 & 26 & 14 & 7 & 0 & 5 & 4 & 42 & 47 & 7 & 0 \\
\hline 8 October 2020 & 5 & 20 & 33 & 27 & 12 & 4 & 1 & 0 & 1 & 21 & 50 & 20 & 8 & 0 \\
\hline 9 October 2020 & 0 & 7 & 27 & 39 & 19 & 6 & 3 & 0 & 2 & 4 & 40 & 46 & 7 & 3 \\
\hline 10 October 2020 & 0 & 5 & 28 & 23 & 11 & 2 & 5 & 0 & 4 & 4 & 27 & 31 & 6 & 2 \\
\hline 11 October 2020 & 0 & 6 & 25 & 35 & 25 & 6 & 3 & 0 & 4 & 18 & 39 & 29 & 6 & 4 \\
\hline 12 October 2020 & 0 & 5 & 23 & 37 & 26 & 11 & 5 & 0 & 8 & 4 & 46 & 41 & 7 & 1 \\
\hline 13 October 2020 & 0 & 5 & 23 & 34 & 26 & 13 & 5 & 0 & 7 & 4 & 47 & 41 & 6 & 1 \\
\hline 14 October 2020 & 5 & 23 & 34 & 26 & 13 & 3 & 3 & 0 & 2 & 18 & 50 & 26 & 9 & 1 \\
\hline 15 October 2020 & 0 & 11 & 30 & 33 & 24 & 7 & 1 & 0 & 6 & 20 & 43 & 31 & 5 & 2 \\
\hline 16 October 2020 & 0 & 12 & 34 & 33 & 15 & 6 & 0 & 0 & 8 & 4 & 53 & 31 & 4 & 0 \\
\hline 17 October 2020 & 0 & 10 & 32 & 35 & 15 & 6 & 3 & 0 & 5 & 4 & 43 & 39 & 6 & 3 \\
\hline 18 October 2020 & 13 & 28 & 30 & 18 & 7 & 1 & 1 & 0 & 8 & 29 & 44 & 20 & 0 & 0 \\
\hline 19 October 2020 & 0 & 13 & 37 & 33 & 14 & 6 & 3 & 0 & 2 & 24 & 45 & 27 & 7 & 1 \\
\hline 20 October 2020 & 4 & 17 & 27 & 20 & 9 & 3 & 0 & 6 & 18 & 34 & 17 & 5 & 0 & 0 \\
\hline 21 October 2020 & 4 & 16 & 31 & 28 & 12 & 3 & 1 & 0 & 6 & 19 & 38 & 25 & 7 & 0 \\
\hline Number of choices & 31 & 212 & 551 & 629 & 393 & 154 & 73 & 6 & 109 & 243 & 830 & 661 & 140 & 54 \\
\hline Percentage of choices & 1.52 & 10.38 & 26.97 & 30.79 & 19.24 & 7.54 & 3.57 & 0.29 & 5.34 & 11.89 & 40.63 & 32.35 & 6.85 & 2.64 \\
\hline Amount of data & & & & & & & 2043 & & & & & & & 2043 \\
\hline Percentage of total & & & & & & & 100 & & & & & & & 100.00 \\
\hline
\end{tabular}


Figures 3, 4, and 5 show the scatter plots and linear regression of the operating temperature (To) against the predicted PMV, TSV, and TCV during the day. With operating temperatures ranging from $29.2^{\circ} \mathrm{C}$ to $31.0^{\circ} \mathrm{C}$, the neutral temperature $(\mathrm{Tn})$ obtained from the PMV model is $27.6^{\circ} \mathrm{C}$ (To). This predicted neutral temperature is lower than the actual choice of the TSV scale and the TCV scale which are $30.3^{\circ} \mathrm{C}$ (To) and $29.7^{\circ} \mathrm{C}$ (To), respectively. Figures 6,7 , and 8 are scatter plots and linear regression of operating temperature (To) against predicted PMV, TSV, and TCV at night. With operating temperatures ranging from $27.7^{\circ} \mathrm{C}$ to $29.5^{\circ} \mathrm{C}$, the neutral temperature $\left(T_{n}\right)$ obtained from the PMV model is $26.2^{\circ} \mathrm{C}$
$\left(T_{0}\right)$. As with the linear regression results during the day, the predicted neutral temperature is also lower than the actual choice of the TSV scale and the TCV scale which are $28.8^{\circ} \mathrm{C}\left(\mathrm{T}_{\mathrm{o}}\right)$ and $28.2^{\circ} \mathrm{C}\left(\mathrm{T}_{\mathrm{o}}\right)$, respectively.

The neutral temperature $\left(\mathrm{T}_{\mathrm{n}}\right)$ obtained from the relationship between the actual choice (TSV and TCV) and the operational temperature $\left(\mathrm{T}_{\mathrm{o}}\right)$ between day and night shows a significantly different number. On the TSV scale there is a neutral temperature difference between day and night of $1.5^{\circ} \mathrm{C}$. On the TCV scale there is a neutral temperature difference of $3.5^{\circ} \mathrm{C}$. Meanwhile, there is a neutral temperature difference predicted on the PMV scale between day and night of $1.4^{\circ} \mathrm{C}$.

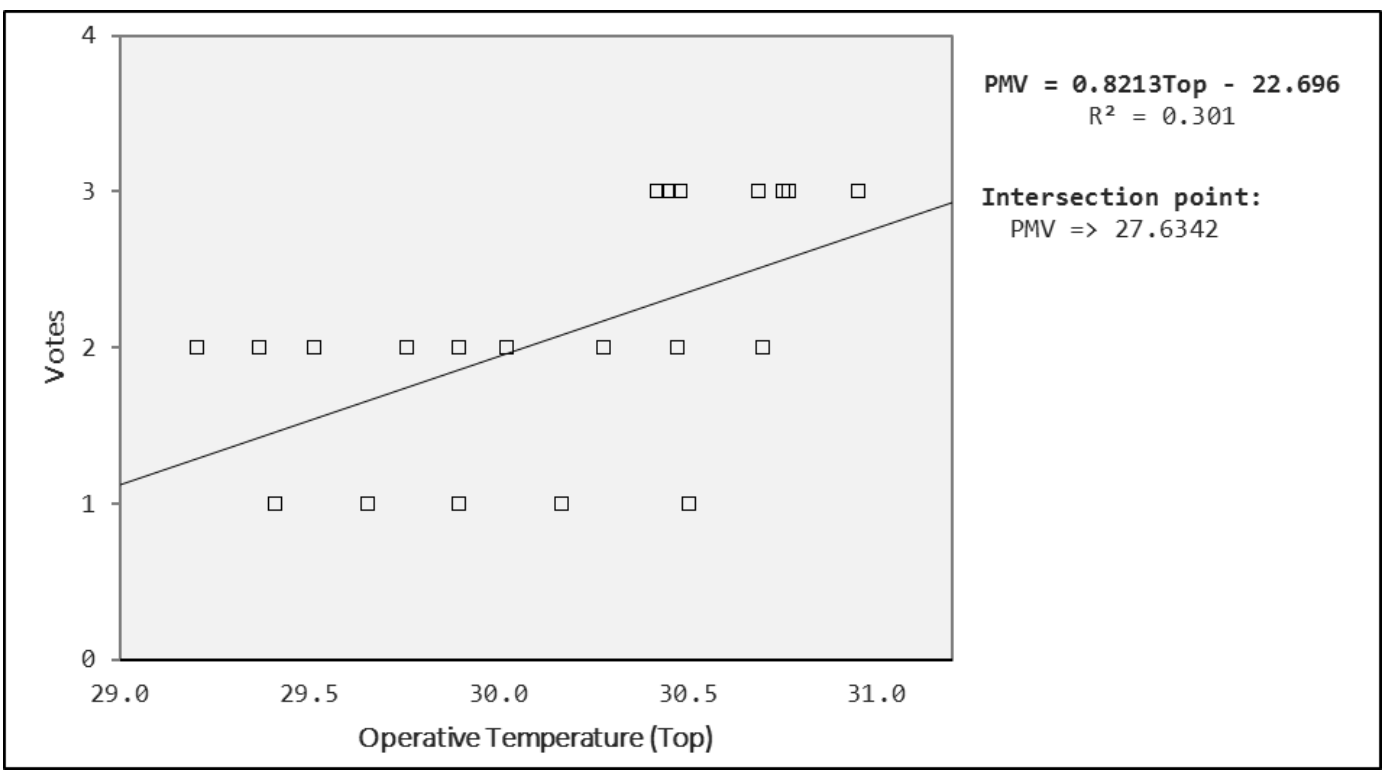

Figure 3. The Scatterplots and the Linier Regressions of the Operative Temperature $\left(\mathrm{T}_{0}\right)$ Versus the PMV During the Day

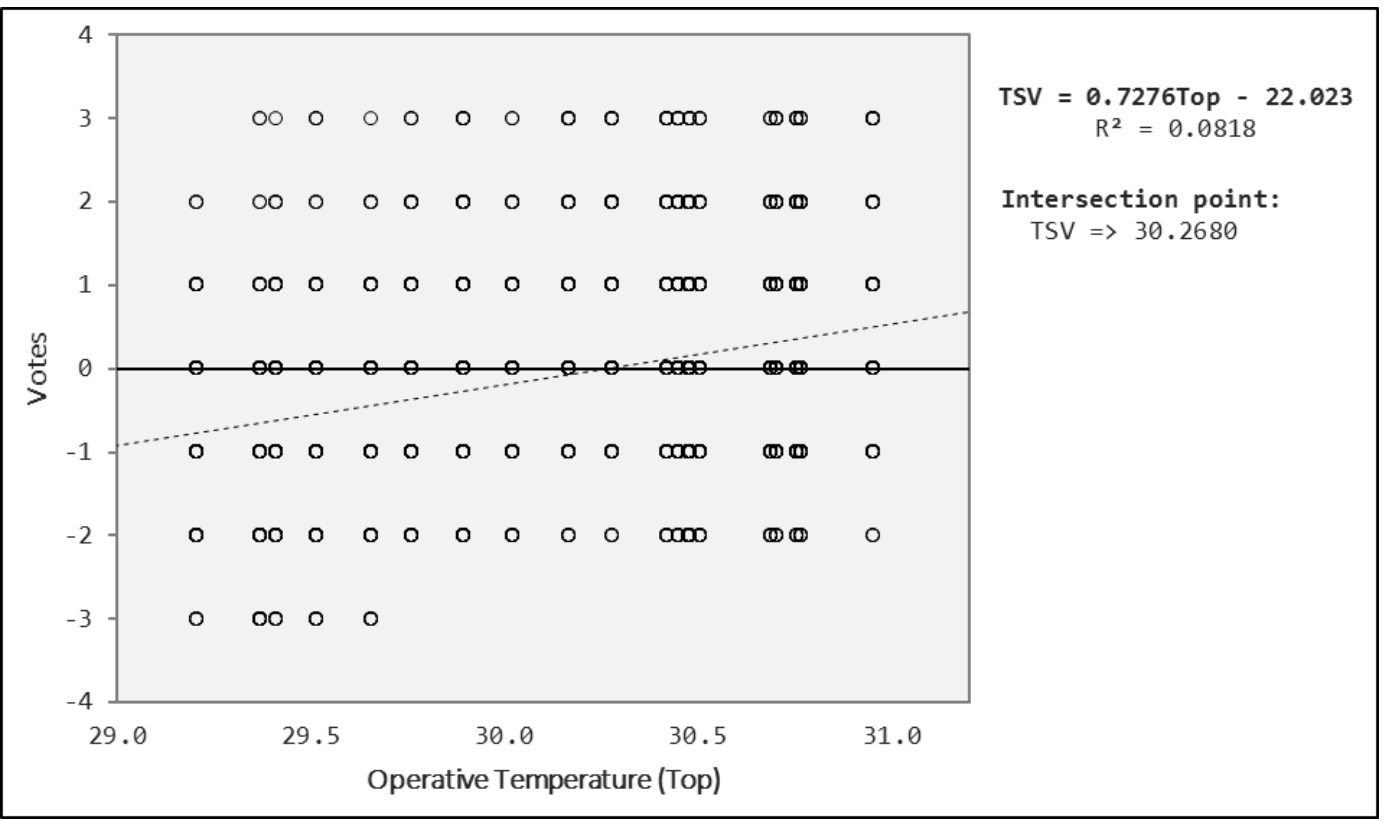

Figure 4. The Scatterplots and the Linier Regressions of the Operative Temperature $\left(T_{0}\right)$ Versus the TSV During the Day 


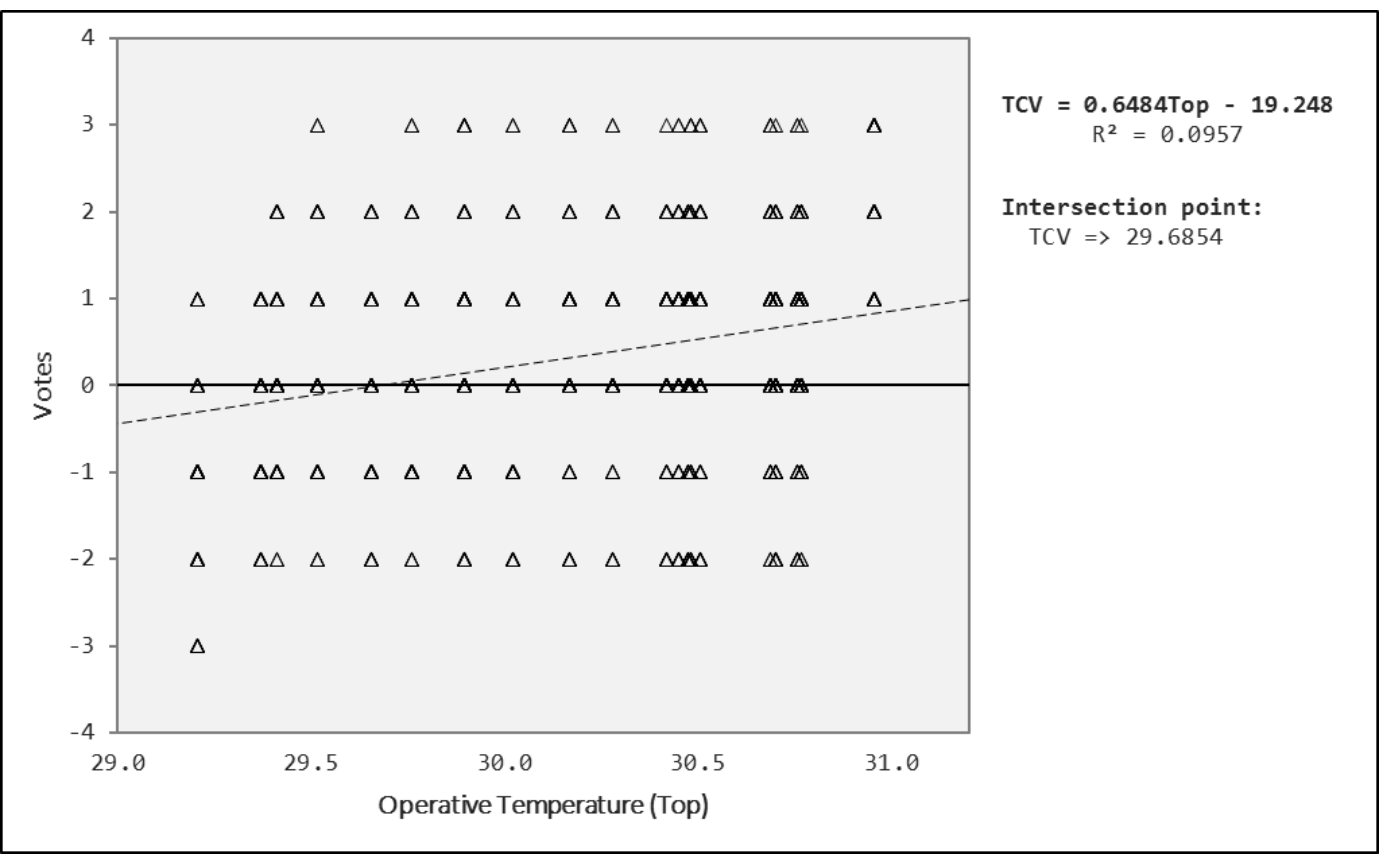

Figure 5. The Scatterplots and the Linier Regressions of the Operative Temperature $\left(T_{0}\right)$ Versus the TCV During the Day

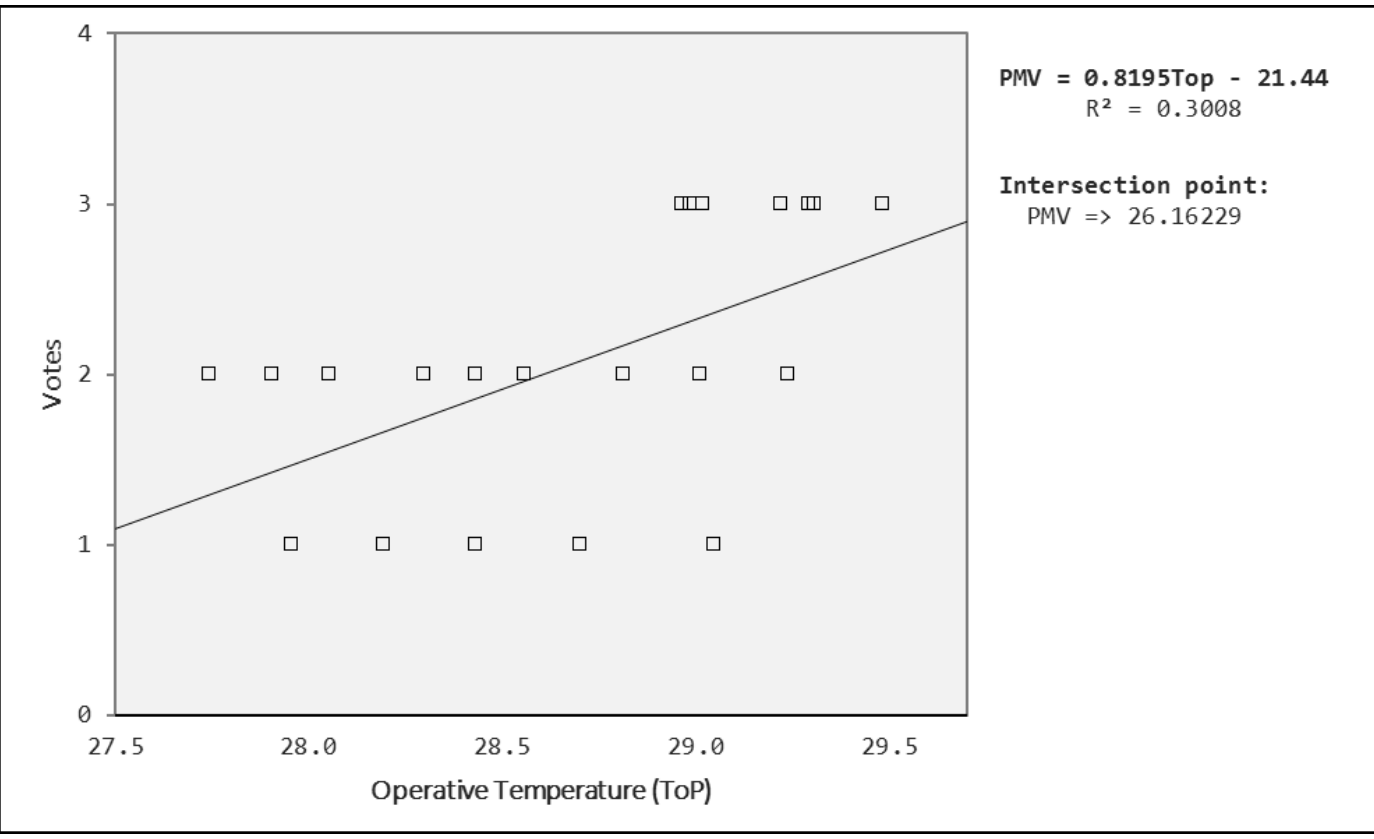

Figure 6. The Scatterplots and the Linier Regressions of the perative Temperature $\left(T_{0}\right)$ Versus the PMV During the Evening 


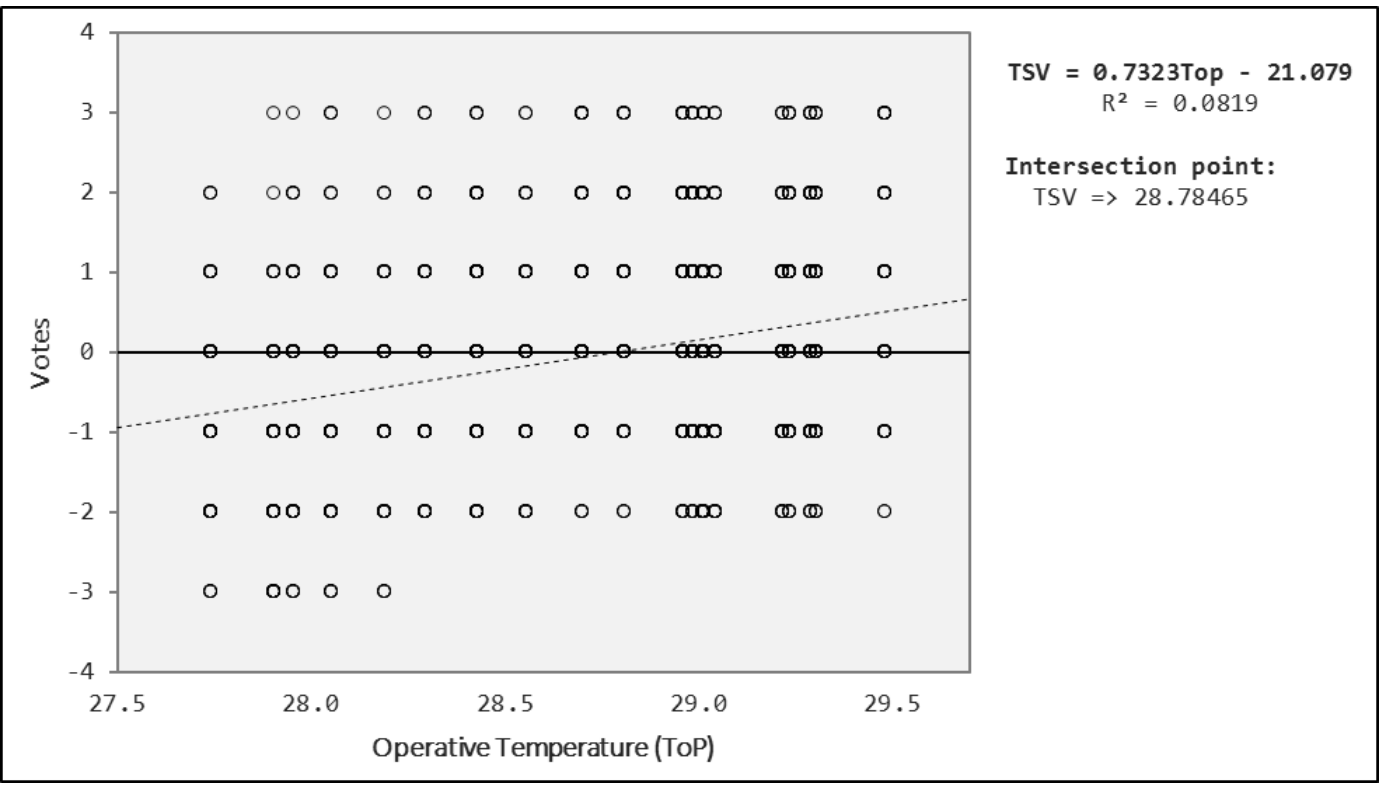

Figure 7. The Scatterplots and the Linier Regressions of the perative Temperature $\left(\mathrm{T}_{\mathrm{o}}\right)$ Versus the TSV During the Evening

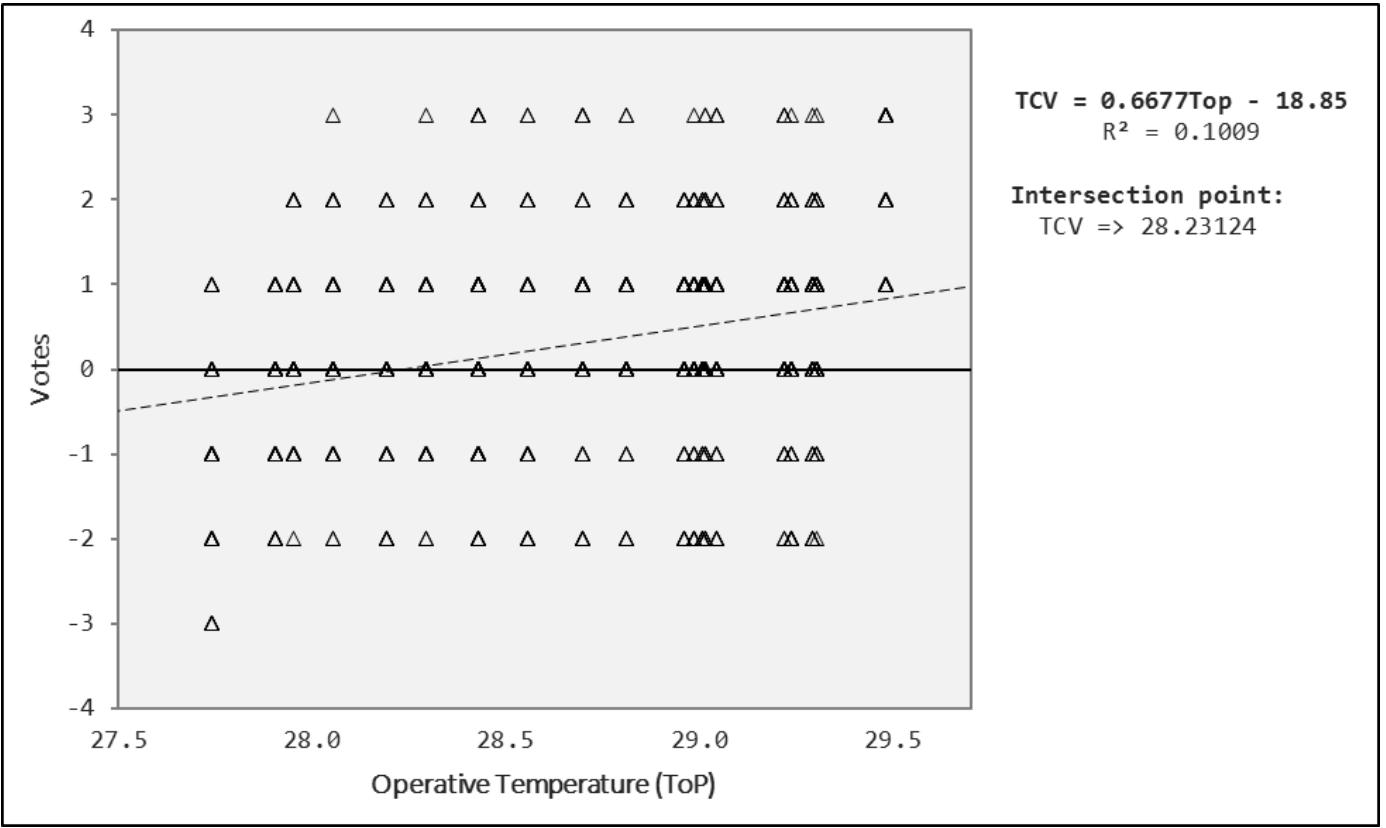

Figure 8. The Scatterplots and the Linier Regressions of the perative Temperature $\left(T_{0}\right)$ Versus the TCV During the Evening

\subsection{Respondent/Occupant Adaptive Activities}

Adaptive activities carried out by respondents / residents in responding to thermal conditions in the room during the day or at night are by setting windows to a wide open position, opening doors, using paper fans, using battery-powered mechanical fans, and some rooms using electric fans. The use of air conditioning in the room was not found because the flats management policy did not allow the use of air conditioning due to considerations of limited electrical resources on campus. Other adaptive activities carried out by residents are leaving the room and joining a study room where the occupants are relatively better because of the sufficient number of window openings.

\subsection{Elaboration of Equations on Neutral Temperature Measurement Results}

The neutral temperature equations which are the object of study in this study are the six neutral temperature equations proposed by Humphrey, Auliciem, Auliciem and de Dear, Nicol and Roaf, respectively, as described in equation (1-6) above. With an actual neutral temperature of $30.3^{\circ} \mathrm{C}$ (TSV), an average outdoor temperature of $29.6^{\circ} \mathrm{C}$, an average indoor temperature of $31.6^{\circ} \mathrm{C}$, then the average neutral temperature of the 6 equations with respect to daylight measurement results the day is as follows: 
1. The Humphrey's Equation

2. The Humphrey's Equation

3. The Humphrey's Equation

4. The Auliciem's Equation

5. Auliciem dan de Dear's Equation

6. Nicol dan Roaf's Equation

Next, on th equation (1): $\mathrm{T}_{n}=11,9+0,534 \mathrm{~T}_{\text {out }}$, if 11.9 assumed to be the thermal constant (x), then the value of $x$ $=14.5$. Thus, the neutral temperature equation corresponding to the actual measurement results is:

$$
\mathrm{T}_{n}=14.5+0.534 \mathrm{~T}_{\text {out }}
$$

Equation (2) will be the same as the result of the elaboration of equation (1) because the multiplier for the outdoor temperature $\left(\mathrm{T}_{\text {out }}\right)$ is the same.

Furthermore, for equation (3): $\mathrm{T}_{n}=13.5+0.546 \mathrm{~T}_{\text {out }}$, if 13.5 is assumed to be the thermal constant (x), then the value of $x=14.1$. Thus, the neutral temperature equation corresponding to the actual measurement results is:

$$
\mathrm{T}_{n}=14.1+0.546 \mathrm{~T}_{\text {out }}
$$

Regarding equation (4): $\mathrm{T}_{n}=9.22+0.48 \mathrm{~T}_{a}+0.14 \mathrm{~T}_{\text {out }}$, if 9.22 is assumed to be the thermal constant (x), then the value of $x=10.99$. Thus, the neutral temperature equation corresponding to the actual measurement results is:

$$
\mathrm{T}_{n}=10.99+0.48 \mathrm{~T}_{a}+0.14 \mathrm{~T}_{\text {out }}
$$

Regarding equation (5): $\mathrm{T}_{n}=17.6+0.31 \mathrm{~T}_{\text {out }}$, if 17.6 is considered as the thermal constant $(\mathrm{x})$, then the value of $x=21.23$. Thus, the neutral temperature equation corresponding to the actual measurement results is:

$$
\mathrm{T}_{n}=21.23+0.31 \mathrm{~T}_{\text {out }}
$$

Regarding equation (6): $\mathrm{T}_{n}=17+0.38 \mathrm{~T}_{\text {out }}$, if 17 is assumed to be the thermal constant ( $\mathrm{x}$ ), then the value of $x=21.23$. Thus, the neutral temperature equation corresponding to the actual measurement results is:

$$
\mathrm{T}_{n}=19.06+0.38 \mathrm{~T}_{\text {out }}
$$

With the actual measured neutral temperature (TSV) of $28.8^{\circ} \mathrm{C}$, an average outdoor temperature of $26.4^{\circ} \mathrm{C}$ and an average indoor temperature of $29.2{ }^{\circ} \mathrm{C}$ at night, the mean neutral temperature is obtained based on each equation as following:

1. The Humphrey's Equation $\quad$ (1) $: 26.0^{\circ} \mathrm{C}$

2. The Humphrey's Equation $\quad$ (2) $: 27.3^{\circ} \mathrm{C}$

3. The Humphrey's Equation $\quad$ (3) $: 27.9^{\circ} \mathrm{C}$

4. The Auliciem's Equation (4) $: 26.9^{\circ} \mathrm{C}$

5. Auliciem and de Dear's Equation (5) $: 25.8^{\circ} \mathrm{C}$

6. Nicol and Roaf's Equation (6) $: 27.0^{\circ} \mathrm{C}$

Furthermore, for equation (1): $\mathrm{T}_{n}=11.9+0.534 \mathrm{~T}_{\text {out }}$, if 11.9 is assumed to be the thermal constant (x), then the value of $x=14.7$. Thus, the neutral temperature equation corresponding to the actual measurement results is:

$$
\mathrm{T}_{n}=14.7+0.534 \mathrm{~T}_{\text {out }}
$$

Furthermore, for equation (3): $\mathrm{T}_{n}=13.5+0.546 \mathrm{~T}_{\text {out }}$, if 13.5 is assumed to be the thermal constant (x), then the value of $x=14.4$. Thus, the neutral temperature equation corresponding to the actual measurement results is:

$$
\mathrm{T}_{n}=14.4+0.546 \mathrm{~T}_{\text {out }}
$$

Regarding equation (4): $\mathrm{T}_{\mathrm{n}}=9.22+0.48 \mathrm{~T}_{\mathrm{a}}+0.14 \mathrm{~T}_{\text {out }}$, if 9.22 is assumed to be the thermal constant (x), then the value of $x=11.9$. Thus, the neutral temperature equation corresponding to the actual measurement results is:

$$
\mathrm{T}_{n}=11.09+0.48 \mathrm{~T}_{a}+0.14 \mathrm{~T}_{\text {out }}
$$

Regarding equation (5): $\mathrm{Tn}=17.6+0.31$ Tout, if 17.6 is considered as the thermal constant (x), then the value of $\mathrm{x}=20.7$. Thus, the neutral temperature equation corresponding to the actual measurement results is:

$$
\mathrm{T}_{n}=20.7+0.31 \mathrm{~T}_{\text {out }}
$$

Regarding equation (6): $\mathrm{T}_{n}=17+0.38 \mathrm{~T}_{\text {out }}$, if 17 is assumed to be the thermal constant (x), then the value of $\mathrm{x}=18.77$. Thus, the neutral temperature equation corresponding to the actual measurement results is:

$$
\mathrm{T}_{n}=18.77+0.38 \mathrm{~T}_{\text {out }}
$$

Furthermore, the comparison of the neutral temperature values for each of the equations of the day and night measurement results can be seen in Table 6 below:

Table 6. Comparison of The Neutral Temperature Value of Each Equation from the Day and Night Measurement Results

\begin{tabular}{|c|c|c|c|}
\hline $\begin{array}{c}\text { Neutral Temperature } \\
\text { Equation Model }\end{array}$ & $\begin{array}{c}\text { Neutral Temperature } \\
\text { Equation }\end{array}$ & $\begin{array}{c}\text { The Proposed Value of the } \\
\text { Daytime Neutral Temperature } \\
\text { Equation Constant }\end{array}$ & $\begin{array}{c}\text { The Proposed Value of the } \\
\text { Nighttime Neutral Temperature } \\
\text { Equation Constant }\end{array}$ \\
\hline $\begin{array}{c}\text { The Humphrey's Equation } \\
\text { Model (eq.1) }\end{array}$ & $\mathrm{T}_{n}=11,9+0,534 \mathrm{~T}_{\text {out }}$ & $\mathrm{T}_{n}=27.7^{\circ} \mathrm{C}$ & $\mathrm{T}_{n}=26.0{ }^{\circ} \mathrm{C}$ \\
\hline $\begin{array}{c}\text { The Humphrey's Equation } \\
\text { Model (eq.2) }\end{array}$ & $\mathrm{T}_{n}=13,2+0,534 \mathrm{~T}_{\text {out }}$ & $\mathrm{T}_{n}=29.0^{\circ} \mathrm{C}$ & $\mathrm{T}_{n}=27.3{ }^{\circ} \mathrm{C}$ \\
\hline $\begin{array}{c}\text { The Humphrey's Equation } \\
\text { Model (eq.3) }\end{array}$ & $\mathrm{T}_{n}=13.5+0.546 \mathrm{~T}_{\text {out }}$ & $\mathrm{T}_{n}=29.7^{\circ} \mathrm{C}$ & $\mathrm{T}_{n}=26.9^{\circ} \mathrm{C}$ \\
\hline $\begin{array}{c}\text { The Auliciem's Equation } \\
\text { Model (eq. 4) }\end{array}$ & $\mathrm{T}_{n}=9.22+0.48 \mathrm{~T}_{a}+0.14 \mathrm{~T}_{\text {out }}$ & $\mathrm{T}_{n}=28.5^{\circ} \mathrm{C}$ & $\mathrm{T}_{n}=25.8{ }^{\circ} \mathrm{C}$ \\
\hline $\begin{array}{c}\text { The Auliciem \& de Dears's } \\
\text { Equation Model (eq. 5) }\end{array}$ & $\mathrm{T}_{n}=17.6+0.31 \mathrm{~T}_{\text {out }}$ & $\mathrm{T}_{n}=26.8{ }^{\circ} \mathrm{C}$ & $\mathrm{T}_{n}=27.0{ }^{\circ} \mathrm{C}$ \\
\hline $\begin{array}{c}\text { The Nicol \& Roafs's } \\
\text { Equation Model (eq. 6) }\end{array}$ & $\mathrm{T}_{n}=17.0+0.38 \mathrm{~T}_{\text {out }}$ & $\mathrm{T}_{n}=28.2{ }^{\circ} \mathrm{C}$ & \\
\hline
\end{tabular}


The data presented in table 6 above shows that the constant value of equation (3) from the daytime measurement results is the value closest to the thermal comfort figure based on the TSV scale measurement $\left(30.3^{\circ} \mathrm{C}\right)$. Likewise, the results of night measurements where equation (3) is the closest value to the TSV scale neutral temperature $\left(28.8^{\circ} \mathrm{C}\right)$. Furthermore, the proposed neutral temperature equation from daytime calculations is shown in Figure 9, while the proposed neutral temperature equation from nighttime calculations is shown in Figure 10.

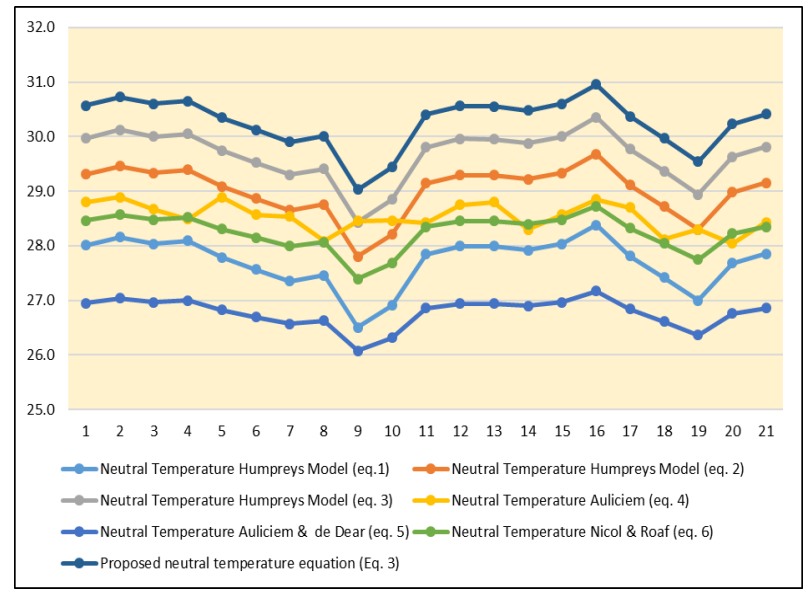

Figure 9. Proposed Neutral Temperature Equation for Daytime Measurement Results (eq. 3)

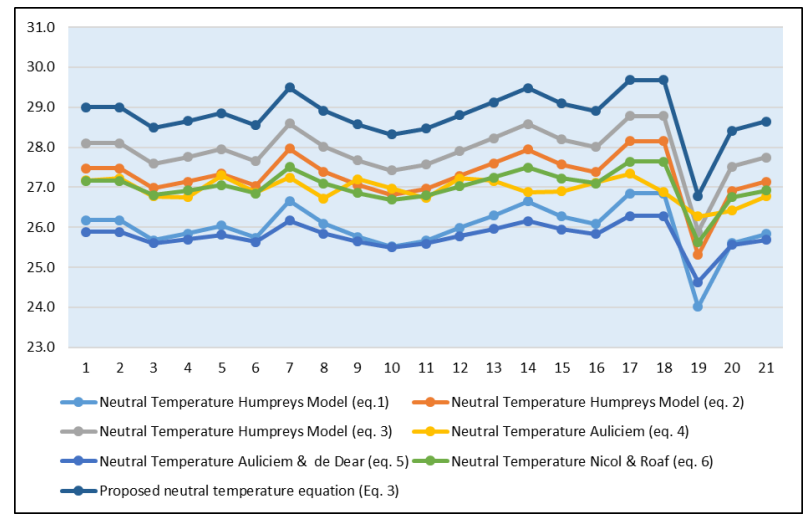

Figure 10. Proposed Neutral Temperature Equation for Nighttime Measurement Results (eq. 3)

\section{Conclusions}

Based on the analysis of the research, it can be concluded that the PMV model used to measure the level of thermal comfort in the tropics, especially in the research location, cannot produce real thermal comfort figures which are marked by a significant difference between the PMV measurement results and the respondents' actual choices (TSV and TCV). There is a difference significant between the neutral temperature predicted by PMV both in the daytime measurement and the nighttime measurement.
In the daytime measurement, with operating temperatures ranging from $29.2^{\circ} \mathrm{C}$ to $31.0^{\circ} \mathrm{C}$, the neutral temperature $\left(\mathrm{T}_{\mathrm{n}}\right)$ obtained from the PMV model is $27.6^{\circ} \mathrm{C}\left(\mathrm{T}_{\mathrm{o}}\right)$. This predicted neutral temperature is lower than the actual choice of the TSV scale and the TCV scale which are $30.3^{\circ} \mathrm{C}\left(\mathrm{T}_{0}\right)$ and $29.7^{\circ} \mathrm{C}\left(\mathrm{T}_{\mathrm{o}}\right)$, respectively. At night measurements, with an operating temperature ranging from $27.7^{\circ} \mathrm{C}$ to $29.5^{\circ} \mathrm{C}$, the neutral temperature (Tn) obtained from the PMV model is $26.2^{\circ} \mathrm{C}$ (To). As with the daytime measurement, the neutral temperature obtained from the respondents' actual choice (TSV and TCV) was $28.8^{\circ} \mathrm{C}\left(\mathrm{T}_{\mathrm{o}}\right)$ and $28.2^{\circ} \mathrm{C}\left(\mathrm{T}_{\mathrm{o}}\right)$, respectively. The neutral temperature equations presented in the Humphrey, Auliciem, de Dear, Nicol, and Roaf equations (equations 1-6) have a thermal constant that is relatively lower than the thermal constant of the actual measurement results carried out in this study, both from the results of daytime measurements, as well as from the results of night measurements. Therefore, this study proposes an alternative neutral equation suitable for tropical areas.

\section{Acknowledgments}

We express our sincere gratitude to friends of the Doctoral Program students from the Laboratory of Building Science and Technology, Department of Architecture, Faculty of Engineering, Hasanuddin University, and special thanks are given to Hafid and all students and respondents who have helped us in the process of measuring and collecting field data.

\section{REFERENCES}

[1] Paliaga G, Schoen LJ, Alspach PF, Arens EA, Aynsley RM, Bean R, et al. Thermal environmental conditions for human occupancy. ASHRAE Stand. 2013;8400(STANDARD 55): $1-44$.

https://ashrae.iwrapper.com/ASHRAE_PREVIEW_ONLY _STANDARDS/STD_55_2013.

[2] Zhao R, Sun S, Ding R, Conditioning strategies of indoor thermal environment in warm climates, Energy and Buildings, Vol. 36, No. 12, pp. 1281-1286, 2004. DOI: 10.13189/ujer.2020.080849.

[3] Perez L, A review on buildings energy consumption information, Vol. 40, No. 3, pp. 394-398, 2008. DOI: 10.1016/j.enbuild.2007.03.007

[4] Olgyay V. Design with climate: Bioclimatic approach to architectural regionalism: New and expanded edition. Design with Climate: Bioclimatic Approach to Architectural Regionalism: New and Expanded Edition. New Jersey: Princeton University Press; 2015. 1-190 p.

[5] Harimi D, Ming CC, Kumaresan S, A Conceptual review on residential thermal comfort in the humid tropics, International Journal of Engineering Innovation \& Research, 
Vol. 1, No. 6, pp. $539 \quad-\quad 544, \quad 2012$. https://www.researchgate.net/profile/Harimi_Djamila/publi cation/282292620_A_Conceptual_Review_on_Residential Thermal_Comfort_in_the_Humid_Tropics/links $/ 560 \mathrm{abe} 9 \mathrm{~b} \overline{0}$ 8ae840a08d66b45/A-Conceptual-Review-on-Residential-T hermal-Comfort-in-the-Humid-Tropics.pdf

[6] Fanger P, Calculation of thermal comfort - introduction of a basic comfort equation, ASHRAE Transactions, Vol. 73, 1967.

[7] Fanger PO, Hojbjerre J, Thomsen JOB, Man's preferred ambient temperature during the day, ARCHSCIPHYSIOL, 1973

[8] Fanger PO, Östberg O, McK. Nicholl AG, Breum NO, Jerking E, Thermal Comfort Conditions During Day and Night, European Journal of Applied Physiology and Occupational Physiology, Vol. 33, No. 4, pp. 255-263, 1974. DOI: $10.1007 / \mathrm{BF} 00430233$

[9] Karyono TH, Heryanto S, Faridah I, Air Conditioning and the neutral temperature of the Indonesian University Students, Architectural Science Review, Vol. 58, No. 2, pp. 174-183, 2015. DOI: 10.1080/00038628.2014.1002828

[10] Hamzah B, Gou Z, Mulyadi R, Amin S, Thermal comfort analyses of secondary school students in the tropics, Buildings, Vol. 8, No. 4, pp. 1 - 19, 2018. DOI: 10.3390 /buildings 8040056

[11] Zaki SA, Damiati SA, Rijal HB, Hagishima A, Abd Razak A, Adaptive thermal comfort in university clasrooms in Malaysia and Japan, Building and Environment, Vol. 122, pp. 294 - 306, DOI: 10.1016/j.buildenv.2017.06.016

[12] Wong NH, Khoo SS, Thermal comfort in classrooms in the tropics, Energy and Buildings, Vol. 35, No. 4, pp. 337 - 351, 2003. DOI: $10.1016 / \mathrm{S} 0378-7788(02) 00109-3$

[13] Eddy J, Alspach PF, Arens EA, Aynsley RM, Bean R, Hartman TB, et al, Thermal environmental conditions for human occupancy, ASHRAE Standard 55, 2017. https://www.ashrae.org/technical-resources/bookstore/stand ard-55-thermal-environmental-conditions-for-human-occup ancy

[14] Hamzah B, Mulyadi R, Amin S, Kusno A, Adaptive thermal comfort of naturally ventilated classrooms of elementary schools in the tropics, IOP Conference Series: Earth and Environmental Science, Vol. 402, 2019. DOI:

\section{$10.1088 / 1755-1315 / 402 / 1 / 012021$}

[15] Karyono TH, Kenyamanan termal dan penghematan energi: Teori dan realisasi dalam desain arsitektur (Thermal comfort and energy saving: Theory and realization in architectural design), 2010. https://www.researchgate.net/publication/30 $5188224 \% 5$ Cnkenyamanan.

[16] RI. KP. Permen PU Republik Indonesia No. 5 Tahun 2007 Tentang Persyaratan Teknis Rumah Susun (Minister of Public Works of the Republic of Indonesia No. 5 of 2007 concerning Technical Requirements for Flats). 2007.

[17] BSN (Badan Standarisasi Nasional), Tata Cara Perancangan Sistem Ventilasi dan Pengkondisian Udara pada Bangunan Gedung (The Procedure of Designing Ventilation and Air Conditioning Systems in Buildings), pp. 1-55, 2001. http://staffnew.uny.ac.id/upload/132100514/pendidikan/per encanaan-pendingin.pdf

[18] Roaf S, Nicol F, Humphreys M, Tuohy P, Boerstra A, Twentieth century standards for thermal comfort: Promoting high energy buildings, Architectural Science Review, Vol. 53, No. 1, pp. 65-77, 2010. DOI: 10.3763/asre.2009.0111

[19] Humphreys MA. Bioengineering, thermal physiology and comfort. Cena, K, Clark JA, editor. Elseiver Scientific Publishing Company; 1981.

[20] Humphreys MA, Nicol JF, Outdoor temperature and indoor thermal comfort: raising the precision of the relationship for the 1998 ASHRAE database of field studies. ASHRAE Transactions 2000;106(February).

[21] Raja IA, Nicol F, A technique for recordinga and analysis of postural changes associated with thermal comfort, Applied Ergonomics, Vol. 28, No. 3, pp. 221-225, 1997. DOI: 10.1016/S0003-6870(96)00036-1

[22] Auliciems A, De Dear R, Airconditioning in Australia I human thermal factors, Architectural Science Review, Vol. 29, No. 3, pp. 67-75, 1986. DOI: 10.1080/00038628.1988.9 697267

[23] Nicol F, Roaf S, Pioneering new indoor temperature standars: The Pakistan Project, Energy and Buildings, Vol. 23, No. 3, pp. 169-74, 1996. DOI: 10.1016/0378-7788(95)00941-8

[24] Farina A, PMV Calculator [Internet], 2015. http://www.angelofarina.it/Public/Fisica-Tecnica-Ambienta le-\%0A2015/Lez-04-05/PMV_cal_tanabe6.xls 